\title{
A Critical Appraisal of the Existing Practices during Practicum in Pakistani Teacher Education Programmes
}

\author{
Anam Iqbal ${ }^{1}$, Samina Naseem ${ }^{2}$, Shafia Azam $^{3}$
}

\begin{abstract}
This survey study explores and discusses the implementation of practicum model for B.Ed (Hons.) Elementary Programme provided by USAID and Higher Education Commission, Pakistan in three different teacher education institutions of Rawalpindi and Islamabad. All 60 Student Teachers (STs) were taken as a sample. Data were collected through a questionnaire from the students enrolled in Semester VIII. The questionnaire comprised of open and close ended questions, based on week-wise tasks mentioned in the Practicum Guidebook. Results of the study reveal that all three Teacher Education institutions are implementing teaching practicum based on their own priorities. In addition, the analysis reveals that STs of two institutions are providing more opportunities to practice the expected tasks. However, all three institutions must enhance STs' lesson planning and reflective skills by providing opportunities for observing cooperative teachers teach, co-planning, triad meetings and regular seminars. It is also recommended to use National Professional Standards for Teachers for assessing STs' skills.
\end{abstract}

Keywords: Practicum Model, Student Teachers, Teaching Practicum, National Professional Standards for Teachers

\section{Introduction}

In 2009, four- year B.ED (Hons.) Elementary degree programme (B.EDHons.) was introduced to revamp Teacher Education Programmes (TEPs) in Pakistan. This degree programme is designed to bridge the gap between theory and practice and to ensure that STs do not get a cultural or reality shock (FeimanNemser, 2012) - thus easing their transition from being a ST to a qualified teacher. Besides professional and content- focused courses, another prominent feature of programme, is short and long-term practicum (15 credit hours).

1 M.Phil Scholar, Department of Education, Fatima Jinnah Women University, Rawalpindi Email: anamsafder@yahoo.com

${ }_{2}$ Assistant Professor, Department of Education, Fatima Jinnah Women University, Rawalpindi Email: samina.naseem05@gmail.com

${ }^{3}$ Assistant Professor, Department of Anthropology, Fatima Jinnah Women University, Rawalpindi Email: azam.shafia@gmail.com 
Practicum is designed to provide opportunities to student teachers (STs) to enhance their teaching skills in real classroom settings. Practicum in semesters III, IV, and VII are developmental, whereas practicum in semester VIII is called professional practicum. With so much investment in practicum, STs still face difficulty when hired as teachers. It is argued that one of reasons of STs' difficulties can be in the interpretation and implementation of the Practicum Guidebook by TEPs, based on available resources (human, financial, and physical). Therefore, it is important to study practices of different TEPs and skills their STs are good at. Documentation of existing practices of TEPs during practicum offers two plausible interests. First interest is to critically appraise the practices based on existing literature on best practicum practices. Second, knowledge about each other's best practices can provide prospects for future collaboration between faculties from TEPs.

This paper uses Feiman-Nemser's (2012) “central tasks, conventional arrangements of TEPs, and critical appraisal" (p.106) as an analytical framework to examine the current implementation practices of different TEPs in Rawalpindi and Islamabad. The 'central tasks' refer to practices given in the Practicum Model, 'conventional arrangements of TEPs' refer to the actual implementation practices, and 'critical appraisal' refers to the suggestions to align the actual practices with the implemented ones.

\subsection{Objective of Study}

The major objective of this study is to examine the actual implementation practices versus the practices given in the Practicum Model and to provide research-based suggestions to appraise the existing practices.

\subsection{Research Questions}

The study addresses the following questions based on the analytical framework of central practices, current practices, and critical appraisal (FeimanNemser, 2012).

1. What are the central tasks of B.Ed (Hons.) Elementary Programme as per Guidebook?

2. What are the current practices of TE institutions and how well do these practices address these central tasks?

3. What measures can be taken to appraise the current practices?

\section{Literature Review}

Professionalism, teaching skills and knowledge are crucial for effective teaching (Khalid, 2014). Therefore, to become professional and effective teacher, STs must go through rigorous field experience during teacher preparation. Field experiences usually referred as teaching practicum in TE programmes is designed to provide opportunities for STs to experience the realities of actual 
classroom teaching. In this study, teaching practicum refers to field experiences that help STs to bridge the gap between theory and practice along with acquiring teaching and managing skills under the guidance and supervision of veteran teachers (Endeley, 2014). Henning, Gut, and Beam (2019) refers practicum as "clinical internship' where "teacher candidates [STs] acquire generalisations (theories and principles) about teaching in campus-based courses and then try to apply them in school setting" (p. 5). Learning opportunities and experiences help STs to transition smoothly from being STs to professional teachers (FeimanNemser, 2012). Practicum is useful in STs' professional development, challenging their pedagogical beliefs, developing STs' perceptions related to their roles and responsibilities, enhancing social interaction and skills (such as time \& class management), familiarization with school environment, and developing critical thinking and reflective practices (Acquah \& Partey, 2014; Hamaidi, Al-Shara, Arouri \& Awwad, 2014; Ochanji, Ayot, Kamina, Ondigi \& Kimemia, 2015; Saifi, Sherzaman, Shah, Idrees, \& Zaman, 2013; Wagenaar, 2005; Wambugu, Barmao \& Ngeno 2013). Other aspects that are widely researched are STs' views to improve practicum experience, STs' anxieties and challenges during practicum (Bashir, Malik, Fatima \& Bashir, 2014; Barahmeh, 2016; Mudzielwana \& Maphos, 2014; Ochanji, Ayot, Kamina, Ondigi \& Kimemia, 2015; Ulvik \& Smith, 2011). Many researchers such as (Nakpodia, 2011; Qazi, Rawat, \& Thomas, 2012) found that implementation of practicum in phases is important for STs' learning.

In Pakistani context, several studies were found that explored various aspects of practicum. Researches (such as Mahmood, Kalsoom, Dilshad, \& Butt, 2014; Murtaza, Iqbal, \& Khaleeq, 2016) found that portfolios are a great tool to develop STs as teachers. Mahmood, Kalsoom, Dilshad, and Butt (2014) found that reflective writing in portfolio helps STs to identify classroom problems and enhance their problem solving and decision- making skills as teachers. Studies (e.g., Murtaza, Iqbal, \& Khaleeq, 2016) recommend proper guidance sessions (debriefing) for STs. Research also recommends that CTs must stay in the classroom to observe STs. Others (such as Fatima \& Behlol, 2018; Gujjar, Naoreen, Saifi, \& Bajwa, 2010; Gujjar, Ramzan, \& Bajwa, 2011; Manzar-Abbas \& Lu, 2013; Murtaza, Iqbal, \& Khaleeq, 2016) present some challenges and problems faced by STs, TEPs, and CTs. These studies found that TEPs face issues related to STs' placement, lack of clarity of roles of ST-CT- university triad, CTs' lack of trust in STs' teaching skills, threatening oral feedback rather than constructive, and lack of understanding about the role of practicum in STs' preparation. STs are not given their choice of subject to teach and evaluation strategies are inappropriate, that is, they do to evaluate STs' learning of skills. 
Other studies also suggested that practicum is "undervalued" by CTs - thus explaining why STs do not learn the expected skills.

Some studies critically examine practices of TEPs, offering insights about how practicum experience enhanced STs' skills significantly. For example, Saifi, Sherzaman, Shah, Idrees, and Zaman (2013) found that triad meetings, weekly conferences, and daily meetings with CTs strongly affect STs' pedagogical beliefs and skills. Similarly, Qazi, Rawat, and Thomas (2012) analysed their own TEP and found that practicum enhances STs' practical teaching and classroom skills, such as development and implementation of lesson planning, using teaching aids and classroom management. However, no study was found in Pakistani context that documents existing practices of TE programmes, compare them with the Guidebook and offer critical appraisal. This study offers insights for the academic administration and teacher educators by identifying practicum implementation practices (as per the Guidebook) that need to be revisited to improve STs' learning experiences during practicum and to find ways to learn and collaborate with each other. Teacher educators can reflect-in and reflect-on their own practices as practicum supervisors, making practicum more productive for STs.

\section{Research Methodology}

\subsection{Sample \& Sampling Technique}

Total population sampling technique was used to select all STs $(n=60)$ of B. ED- Hons., in semester VIII from all three TEPs, as a sample after they signed informed consent letter. STs from the final semester were selected purposively to detail a fuller picture of practicum. To keep the anonymity, institutions are referred as IA, IB and IC.

\subsection{Instrumentation}

For this survey study, a self-developed questionnaire, consisting of fortythree closed ended items and nine open ended questions, was used to find out the current practices of TEPs in Rawalpindi and Islamabad. Open-ended questions asked STs to add practices that closed-ended statements did not cover. The tool was validated by six experts from the field of education and was pilot tested. The overall value of Cronbach's alpha for the questionnaire was .873 .

\subsection{Data Collection}

The research was carried out for one and half months in three institutions, out of which two were public institutions and one was semigovernment. Researchers personally visited the institutions to administer the tool. The return rate of questionnaire was 100 percent. However, only 33 STs responded to open-ended questions 


\section{Data Analysis and Interpretation}

Descriptive analysis (percentages and frequencies) was applied. Questions were based on tasks mentioned in the Guidebook (2012). For example, the Guidebook (2012) says, "Complete school-based assignments, which provide you with an opportunity to get to know the school, its resources, the rules, and procedures expected of you" (p. 12). In Table 4.2, statements (i) to (iii) represent this task.

Using Feiman-Nemser's (2012) framework, this section shares results and findings related to the research questions of this study;

\section{Central Tasks}

The Guidebook for developmental practicum in Semester III shows two major central tasks - school placements and practicum seminar. It is also recommended that practicum must be offered III, IV, VII and VIII semesters. The reason and significance of offering practicum twice in beginning and twice at the end of the programme is that it enables STs to develop effective teaching skills and gives them opportunities to refine those skills with time. Other central tasks include STs' teaching observations by university supervisors and CTs and conducting triad meeting and practicum seminars.

\section{School Placements}

The Guidebook (USAID, 2012) recommends placing STs for six weeks twice either in the same school, but different grades or in a different school and teaching different grades than the previous school. For week-wise activities for STs mentioned in the Guidebook (Tables 4.2-4.7).

\section{Current Practices - Major findings}

The Guidebook suggests six-week long practicum and to place STs in both private and public school to give them varied experience. Data analysis revealed that STs' placement varied from the Guidebook except for IA.

Table 4.1

STs' placement in schools

\begin{tabular}{lccc}
\hline \multicolumn{1}{c}{ Recommended Semester \& Duration } & IA & IB & IC \\
\hline III -10 days & 10 days & $10-18$ days & 2 months \\
IV -10 days & 10 days & $10-18$ days & \\
VII -10 days & 10 days & & \\
VIII -1 month & 1 month & & 2 months \\
\hline
\end{tabular}

\section{Observation of Lesson Plans by Supervisors}

The Guidebook advises supervisors to observe STs' teaching at least twice. The number of observations varied from one to two observations for a duration of only for 15-20 minutes rather than observing one's full class. 


\section{Seminars and Meetings}

The Guidebook advises to arrange two seminars during the practicum i.e., midpracticum and end-practicum seminars and two triad meetings during the whole practicum. Unfortunately, this aspect of the model has been overlooked in all three TEPs.

\section{Skills}

Although the Guidebook gives equal importance to the lesson planning, teaching and management skills for STs to become effective teachers, all institutions focus on routine work and management (Table 4.2).

Week 1: The first week is about the provision of opportunities to STs to know about school and classroom environment and to work in collaboration with their CTs. STs' responses in Table 4.2 reveal that practices of IB and IC were more aligned with the tasks mentioned in the Guidebook as compared to IA. Except for opportunities to reflect, STs from IA did not have enough opportunities to be familiar with offices and to assist in administrative tasks.

Table 4.2

School and Classroom Environment

\begin{tabular}{|c|c|c|c|}
\hline Week 1- Statements & IA & IB & $\mathrm{IC}$ \\
\hline i) I was informed about available resources in school. & $66.7 \%$ & $100 \%$ & $100 \%$ \\
\hline $\begin{array}{l}\text { ii) I was informed about school rules that I was expected to } \\
\text { follow. }\end{array}$ & $66.7 \%$ & $92.3 \%$ & $100 \%$ \\
\hline $\begin{array}{l}\text { iii) I was informed about school procedures that I was } \\
\text { expected to follow. }\end{array}$ & $69.2 \%$ & $76.9 \%$ & $100 \%$ \\
\hline $\begin{array}{l}\text { iv) I was familiar with location of different offices (such as } \\
\text { staff room, library, medical aid room etc.). }\end{array}$ & $53.8 \%$ & $76.9 \%$ & $100 \%$ \\
\hline $\begin{array}{l}\text { v) I had given opportunity to learn about placement of } \\
\text { materials in the class. }\end{array}$ & $64.1 \%$ & $100 \%$ & $100 \%$ \\
\hline it the workspaces of the classroom. & $82.1 \%$ & $100 \%$ & $100 \%$ \\
\hline ut the traffic pa & $61.5 \%$ & $76.9 \%$ & $100 \%$ \\
\hline $\mathrm{d}$ CT in small admin & $56.4 \%$ & $84.6 \%$ & $75 \%$ \\
\hline $\begin{array}{l}\text { ix) I had assisted CT in helping individual children and small } \\
\text { groups. }\end{array}$ & $56.4 \%$ & $92.3 \%$ & $100 \%$ \\
\hline $\begin{array}{l}\text { x) I was given the opportunity to discuss instructional planning } \\
\text { of CT with him/her. }\end{array}$ & $76.9 \%$ & $92.3 \%$ & $100 \%$ \\
\hline $\begin{array}{l}\text { xi) I was given the opportunity to discuss CTs' expectations } \\
\text { with him/her regarding my teaching practices. }\end{array}$ & $66.7 \%$ & $84.6 \%$ & $100 \%$ \\
\hline $\begin{array}{l}\text { xii) I was given the opportunity to reflect on my learning of } \\
\text { the week. }\end{array}$ & $87.2 \%$ & $76.9 \%$ & $75 \%$ \\
\hline
\end{tabular}

Week 2: The responses in Table 4.3 reflect that practices of IB and IC were again more aligned with the suggested model. All STs at IA did not have 
opportunity to discuss teaching plan of CT. All STs had fewer opportunities to learn about CTs' educational philosophy.

Table 4.3

Working with Students

\section{Week 2 - Statements}

xiii) I was given opportunities to learn about educational philosophy of the CTs.

xiv) I had learnt about how to work with small group of students and individual students.

xv) I was given the opportunity to observe small group $71.8 \% \quad 92.3 \% \quad 100 \%$ engagement in the classroom.

xvi) I was given the opportunity to observe individual student engagement in classroom.

xvii) I had assisted CT in working with students who needed $\quad 71.8 \% \quad 84.6 \% \quad 87.5 \%$ extra help.

xviii) I had assisted CT in working with small group of $64.1 \% \quad 84.6 \% \quad 87.5 \%$ students to carry out his/her plan.

xix) I was given the opportunity to discuss teaching plan of $\quad 53.8 \% \quad 84.6 \% \quad 87.5 \%$ CT with him/her.

xx) I was given the opportunity to reflect on my learning of $\quad 87.2 \% \quad 92.3 \% \quad 100 \%$ the week.

Week 3: Table 4.4 shows that practices of IB and IC were in line with the Guidebook to much extent. During practicum the major focus was on the development of managerial and routine skills of STs. STs were had fewer opportunities to observe CTs to learn how to teach and engage students.

Table 4.4

Classroom Management and Lesson Planning

Week 3 - Statements

xxi) I learnt about strategies that $\mathrm{CT}$ uses to manage the classroom.

xxii) I was given the opportunity to learn about community (parents and other community members) involvement in the school.

xxiii) I was given the opportunity to observe CT to rewrite lesson plan by adding my own ideas.

xxiv) I was given the opportunity to observe how CTs engage with students.

xxv) I was given the opportunity to co-plan some lessons with CT.

xxvi) I was given the opportunity to take over a routine such as taking children for recess, taking attendance, or reading a story to the class.

\begin{tabular}{lll} 
IA & IB & IC \\
\hline
\end{tabular}

$43.6 \% \quad 70 \% \quad 75 \%$

$43.6 \% \quad 60 \% \quad 62.5 \%$

$56.4 \% \quad 50 \% \quad 50 \%$

$48.7 \% \quad 60 \% \quad 62.5 \%$

$56.4 \% \quad 80 \% \quad 87.5 \%$ 
\begin{tabular}{llllll}
\hline xxvii) I was also given the opportunity to co-teach a few & $46.2 \%$ & $70 \%$ & $75 \%$
\end{tabular} sections with $\mathrm{CT}$.

xxviii) I was given the opportunity to reflect on my learning this $\quad 82.1 \% \quad 70 \% \quad 75 \%$ week.

Week 4: Data analysis in Table 4.5 demonstrates that as compared to IA, practices of IB and IC were more aligned with the model. Learning opportunities to keep track of students' engagement was one of the weakest tasks along with opportunity to reflect in IB and IC.

Table 4.5

Involvement in School and Classroom Activities

\begin{tabular}{lccc}
\hline \multicolumn{1}{c}{ Week $4-$ Statements } & IA & IB & IC \\
\hline $\begin{array}{l}\text { xxix) I learnt about co-curricular activities in which the students } \\
\text { of my class are involved. }\end{array}$ & $48.7 \%$ & $90 \%$ & $87.5 \%$ \\
$\begin{array}{l}\text { xxx) I was given the opportunity to learn that how the CT } \\
\text { manages the classroom during activities. }\end{array}$ & $46.2 \%$ & $70 \%$ & $75 \%$ \\
$\begin{array}{l}\text { xxxi) I was given the opportunity to learn to keep track of } \\
\text { students' engagement by having focus on their on-and-off-task } \\
\text { behaviour. }\end{array}$ & $56.4 \%$ & $60 \%$ & $62.5 \%$ \\
$\begin{array}{l}\text { xxxii) I had assisted CT in managing the class by moving } \\
\text { around the class to monitor students' participation/ discipline. } \\
\text { xxxiii) I was given the opportunity to reflect on my learning of } \\
\text { this week. }\end{array}$ & $79.5 \%$ & $80 \%$ & $87.5 \%$ \\
\hline
\end{tabular}

Week 5: Table 4.6 shows that practices of the three institutions were much aligned with tasks mentioned in the model. However, STs from IA were given less opportunities to assist their CTs as compared to the other two institutions. Moreover, less opportunities of reflection were provided to STs of IC as compared to the STs of the other two institutions.

Table 4.6

\section{Co-planning and Co-teaching}

\begin{tabular}{llll}
\hline \multicolumn{1}{c}{ Week 5-Statements } & IA & IB & IC \\
\hline $\begin{array}{l}\text { xxxiv) I started to file all the assignments and school experience } \\
\text { in my developmental portfolio. }\end{array}$ & $94.9 \%$ & $80 \%$ & $87.5 \%$ \\
xxxv) I had used my notes for my self-assessment to indicate & $64.1 \%$ & $80 \%$ & $75 \%$ \\
that how I am meeting NPSTP. \\
$\begin{array}{l}\text { xxxvi) I was given the opportunity to observe verbal } \\
\text { engagement of children. }\end{array}$ & $82.1 \%$ & $80 \%$ & $87.5 \%$ \\
$\begin{array}{l}\text { xxxvii) I had observed the engagement of children in } \\
\text { classroom. }\end{array}$ & $92.3 \%$ & $80 \%$ & $87.5 \%$ \\
$\begin{array}{l}\text { xxxviii) I had assisted the CT in planning and teaching in at } \\
\text { least one subject area this week. }\end{array}$ & $48.7 \%$ & $70 \%$ & $75 \%$ \\
xxxix) I was given the responsibility of planning and teaching & $84.6 \%$ & $80 \%$ & $100 \%$ \\
\hline
\end{tabular}


of one subject area.

xl) I was given the opportunity to reflect on my learning this $79.5 \% \quad 60 \% \quad 75 \%$ week.

Week 6: Table 4.7 exhibits that STs from all three institutions were not provided with enough learning opportunities to make notes about how they were achieving NPSTP and to assist CTs in lesson planning and teaching.

Table 4.7

Lesson Planning and Teaching

Week 6 - Statements

xi) I had continued to make notes about how I am meeting $\quad 51.3 \% \quad 60 \% \quad 37.5 \%$ NPSTP.

xii) I had assisted $\mathrm{CT}$ in planning and teaching in at least two $\quad 43.6 \% \quad 60 \% \quad 50 \%$ subject areas this week.

xiii) I was given the opportunity to reflect on my learning this $\quad 76.9 \% \quad 60 \% \quad 50 \%$ week.

Based on responses of open-ended questions, STs were also given opportunities to prepare timetable, design and conduct classroom activities, invigilate during exams, and build connection between lesson objectives and students' outcomes. However, STs' responses also established that their skills to manage students and to engage them in classroom were stronger than other teaching skills.

\section{Discussion}

Preparation of effective STs is not only reliant on theoretical knowledge, but also depends on effective and meaningful practicum that provides them opportunities to develop necessary skills and behaviours that improve their teaching practices (Hamaidi, Al-Shara, Arouri \& Awwad, 2014). The results indicate that institutions B and C were not placing STs as recommended in the Guidebook. However, their STs outperformed STs of IA, which followed the Guidebook.

The central tasks given in the Guidebook - school placements and practicum seminar are grounded in the existing literature. For instance, Researchers (e.g., Wagenaar, 2005) emphasise the importance of familiarisation of STs with different teaching environment and opportunities to adjust themselves accordingly. However, STs were not placed in a different school for the second placement - thus limiting their learning experiences to teach in a different context. Furthermore, the results also show that triad meetings and seminars were missing, which literature suggests that enhance STs' teaching skills and beliefs. One significant explanation could be that IA did not have any formal contracts with cooperative schools. Also, cooperative schools and CTs may not find same kind of significance of practicum as TEPs do (Gujjar, 
Naoreen, Saifi, \& Bajwa, 2010). Whereas, it is argued that the Guidebook presents an ideal situation where formal structures are in place. Therefore, it is difficult to provide comprehensive learning opportunities for STs. Furthermore, the analysis confirms that two institutions had reduced the number of times practicum was offered from four to two. This shows that STs do not go through developmental stage to gradually transition from trainee to professional teachers (Feiman-Nemser, 2012; Nakpodia, 2011), yet they were given more opportunities to learn.

The analysis also implies that STs were not observed as recommended, which means less interaction between STs and CTs. This has two major implications; (i) if observed only for a short period of time, feedback provided can be "threatening" rather than constructive (Fatima \& Behlol, 2018); and (ii) less to no interaction between STs and CTs results in weak or no relationship between them, which is one of the major features of effective practicum (Ulvik \& Smith, 2011). Another significant aspect of B.ED-Hons is the NPSTP. The analysis indicates that STs did not learn to teach or were assessed in accordance with these Standards. This means that the three institutions may not be aware whether their STs fulfil the NPSTP criteria or not. Data shows that only one institution provided opportunities to develop reflective practices, which are an important aspect of becoming a life-long learner, becoming a problem solver and a decision maker (Hamaidi, Al-Shara, Arouri \& Awwad, 2014; Mkhasibe, 2014; Starkey \& Rawlins, 2012). Results also showed that the major focus was on the management skills and learning to teach with different strategies and planning accordingly were overlooked thus making them susceptible to sink and swim experience.

The analysis of the week-wise data reveals that STs of each of the institutions were good at different skills. This is consistent with the existing research. Campuses of the same TE programme prepare STs differently (ManzarAbbas \& Lu, 2015). Research (Huma, 2013) found that teacher educators interpret same policies differently in their practices. In other words, teacher educators are also learning about implementation of the Guidebook through sinkand swim. This suggests that teacher educators should be professionally developed to interpret the Guidebook in similar ways. This suggestion does not undermine individual differences. However, the underlined assumption is that teacher educators should at least understand the basic philosophy behind the way practicum is organized.

\section{Conclusion}

The study concludes central tasks mentioned in the Guidebook are aligned with existing research on teacher preparation and STs' learning. 
Although a standardised guidebook is available for teaching practicum, the study concludes that current practices of TE institutions in Rawalpindi and Islamabad, vary from institution to institution and implementation is based on their interpretation of the Guidebook and availability of resources. It is concluded that longer duration provides more opportunities to learn. Therefore, the guidebook may be revisited based on implementation experiences of TEPs. The current study also concludes that professional development for university supervisors and CTs is pertinent for making practicum more coherent with the Guidebook. It is suggested that further research may be conducted to study views of principals and CTs regarding their roles and expertise during six-weeks of practicum. Furthermore, understanding of the NPSTP and their usefulness in teacher preparation should also be studied.

\section{Recommendations}

Based on the findings of study, the following recommendations are made to critically appraise practices, especially in IA.

\section{Offering purposeful \& integrated field experiences}

Practicum experience must be purposefully and carefully arranged to bridge the gap between the actual classroom-based practices and pedagogies taught in the course work. This can be achieved by;

(i) Bringing all stakeholders on-board and familiarizing them with the philosophy behind the format of practicum and the degree programme.

(ii) Being on the same page can facilitate both stakeholders in providing and assessing all aspects - lesson planning and assessment along with the classroom management.

\section{Making the practicum experience coherent}

In each of the institutions, teacher educators must use these findings to revisit the opportunities they provide to their STs. For instance, instead of using self-made evaluation performas, university supervisors can use NPSTP rubric already given, to evaluate STs.

\section{Professional development of university supervisors and CTs}

Professional development opportunities (such as inviting foreign and national experts) should be offered to all teacher educators (who are prospective university supervisors) and CTs. Such a professional development will help in streamlining the practicum experiences. Especially when we think of aligning STs' evaluation with NPSTP. If university supervisors and CTs are professionally developed to use NPSTP as tool to assess STs' teaching, the practice will reduce the gap between theory and practice. Professional development should also focus on how to provide proper feedback to STs on their teaching, lesson planning, and implementation. Furthermore, teacher 
educators do not have expertise in all subject areas - thus STs develop management skills rather than teaching. It is recommended that CTs must be professionally developed to act as school-based teacher educators.

\section{Learning from each other's promising practices}

TE institutions in close vicinity should share expertise with each other. Within each institution, different instructors supervise practicum and teach pedagogical courses. Opportunities to share and discuss practices, expertise, assessment tools, resources, etc., can support teacher educators to explore and develop deep critical perspectives by reflecting on their own teaching. For instance, IC and IB have formalised practicum experiences, whereas IA is good at preparing STs for reflection. These institutions can make a forum where teacher educators can meet and work for betterment of STs' experiences during the practicum.

\section{References}

Acquah, B. Y.S., \& Partey, P.A. (2014). The importance of field experience in teacher preparation: Perspectives of trainee economics teachers in the University of Cape Coast. International Journal of Research in Social Sciences, 4(4), 58-63.

Andabai, P.W. (2013). The impact of teaching practice on trainee teachers in the Nigerian Tertiary Institutions: The Niger Delta University Experience. Academic Journal of Interdisciplinary Studies, 2(5), 109-115.

Barahmeh, M. Y. (2016). A study of sources EFL student-teachers anxiety during their practicum experience. European Journal of Research and Reflection in Educational Sciences, 4(1), 20-23.

Bashir. S., Malik, M., Fatima, G., \& Bashir, S. (2014). Effectiveness of practicum component of B.Ed. program at University of Education Lahore, Pakistan. Educational Research International, 3(4), 89-98.

Endeley, M.N. (2014). Teaching practicum in Cameroon: The effectiveness of university of Buea model and implications for quality. Australian Journal of Teacher Education, 39(11), 147-160.

Fatima, F. M., \& Behlol, M. G. (2018). Mentoring prospective teachers at teaching practicum in B. Ed (Hons) 4 years program. Proceedings of ADVED 2018- 4th International Conference on Advances in Education 
and Social Sciences, 15-17 October 2018- Istanbul, Turkey http://www.ocerints.org/adved18_e-publication/papers/46.pdf

Feiman-Nemser, S. (2012). Teachers as Learners. Cambridge, MA: Harvard Education Press.

Gujjar, A. A., Naoreen, B., Saifi, S., \& Bajwa, M. J. (2010). Teaching practice: Problems and issues in Pakistan. International Online Journal of Educational Sciences, 2(2), 339-361

Gujjar, A. A., Ramzan, M., \& Bajwa, M. J. (2011). An evaluation of teaching practice: practicum. Pakistan Journal of Commerce and Social Sciences (PJCSS), 5(2), 302-318.

Hamaidi, D., Al-Shara, I., Arouri, Y., \& Awwad, F.A.(2014). Student teachers' perspectives of practicum practices and challenges. European Scientific Journal, 10(13), 191-193.

Henning, J. E., Gut, D. M., \& Beam, P. C. (2019). Building mentoring capacity in teacher education: A guide to clinically-based practice. USA, New York: Routledge, Taylor and Francis Group.

Huma, A. (2013). Interpretive analysis of new teacher education curriculum reform introduced in Pakistan (Doctoral dissertation). Available from ProQuest Dissertations and Theses database. (UMI No. 3604657)

Khalid, F. (2014). The impact of teaching practice experience in shaping preservice teachers' professional identities. Mediterranean Journal of Social Sciences, 5(20), 1921-1927.

Mahmood, M. K., Kalsoom, Q., Dilshad, M., \& Butt, I. H. (2014). Professional development portfolio: A tool for student teachers' development. Journal of Educational Research, 17(1), 60-76.

Manzar-Abbas, S., \& Lu, L. (2015). The practicum status in UE campuses during B. Ed. Programme: TEs' perceptions. Journal of Research \& Reflections in Education (JRRE), 9(1), 2-16. 
Manzar-Abbas, S. S., \& Lu, L. (2013). Collaboration problems during practicum in pre-service teacher education in Pakistan. Academic Research International, 4(3), 379-393.

Mkhasibe, R. G. N. (2014). Student teachers 'perceptions of teaching practice at the University of Zululand (Masters Dissertation, University of Zululand South Africa). Retrieved on Jan $8^{\text {th }}, 2019$ from http://www.netd.ac.za/portal/?action=view\&identifier=oai\%3Aunion.ndlt d.org\%3Auzulu \%2Foai\%3Auzspace.uzulu.ac.za\%3A10530\%2F1426

Mudzielwana, P.N \& Maphosa, C. (2014). Trainee teachers' experiences of being observed teaching while on teaching practice: A case of a rural-based university in South Africa. Mediterranean Journal of Social Sciences, 5(16), 393-402.

Murtaza, A., Iqbal, J., \& Khaleeq, A. R. (2016). Practicum portfolio assessment and professional development of pre-service teachers. Pakistan International Journal of Humanities and Social Sciences, 6(2), 194- 202.

Nakpodia, E.D. (2011). Teacher and student practice teaching program in Nigerian educational system. International Journal of Educational Administration and Policy Studies, 2(3), 33-39.

Ochanji, M., Ayot, H., Kamina, P., Ondigi, S., \& Kimemia, J. (2015). Improving student teaching for quality teacher preparation: A Kenyan university use. African Journal of Teacher Education, 4(1), 1-17.

Qazi, W., Rawat, K. J., \& Thomas, M. (2012). The role of practicum in enhancing student teachers' teaching skills. American Journal of Scientific Research, 44(12), 44-57.

Saifi, S., Sherzaman, Shah, S.S. A., Idrees, A., \& Zaman, S. (2013). Effect of reformed teaching practicum on professional development of $\mathrm{B}$. Ed (Hons) prospective teachers. Bulletin of Education and Research, 35(2), 125-138.

Starkey, L., \& Rawlins, P.(2012). Student teachers' learning during practicum experience. Teacher Education Advancement Network, 4(1), 1-19. 
Ulvik, M., \& Smith, K. (2011). What characterizes a good practicum in teacher education? Education Inquiry, 2(3), 517-536.

Lu, H.L. (2011). Three-way conferences facilitated by programme supervisors: Student teachers' perceptions. South Eastern Regional Association of Teacher Educators, 20(2), 1-11.

USAID. (2012). Practicum guide. Teacher Education Project.

Wagenaar, M. (2005). Student teachers' experiences of practice teaching (Master's Dissertation, University of Zululand). Retrieved on Feb $29^{\text {th }}$, 2017 from http://uzspace.uzulu.ac.za/handle/10530/523

Wambugu, P., Barmao, A., \& Ngeno, J. (2013). Student-teachers' perceptions of teaching practice assessment in Egerton University, Kenya. Education Journal, 2(4), 169-175.

\section{Citation of this Article:}

Iqbal, A., Naseem, S., \& Azam, S. (2020). A Critical Appraisal of the Existing Practices during Practicum in Pakistani Teacher Education Programmes. International Journal of Innovation in Teaching and Learning (IJITL), 6(2), 1731. 